\title{
BRACHYTHERAPY FOR STAGE IIIB SQUAMOUS CELL CARCINOMA OF THE UTERINE CERVIX: SURVIVAL AND TOXICITY
}

Antonio Carlos Zuliani ${ }^{1 *}$, Maércio de Oliveira Cunha ${ }^{1}$, Sérgio C. B. Esteves ${ }^{2}$, Júlio César Teixeira ${ }^{3}$, Trabalho realizado na Seção de Radioterapia, Departamento de Tocoginecologia, Universidade Estadual de Campinas, Campinas, SP

\author{
*Correspondência: \\ ADepartamento de \\ Radioterapia, CAISM- \\ Unicamp \\ Rua Alexander Fleming, \\ n० 101 - Cidade \\ Universitária Zeferino Vaz \\ Campinas, SP \\ CEP $13083-881$ \\ aczo.rt@gmail.com
}

\begin{abstract}
SUMMARY
ОвJеctive. To compare survival and toxicity of three different treatments for stage IIIB cervix cancer: low-dose-rate (LDR), high-dose-rate (HDR) brachytherapy and association of HDR and chemotherapy. Methods. Between 1985 and 2005, 230 patients with FIGO stage IIIB squamous cell carcinoma of the uterine cervix received 4-field pelvic teletherapy at doses between 40 and $50.4 \mathrm{~Gy}$, with a different complementation in each group. The LDRB group, with 42 patients, received one or two insertions of LDR, with Cesium-137, in a total dose of 80 to 100Gy at point A. The HDR group, 155 patients received HDR in 4 weekly 7 Gy fractions and 9 Gy to 14.4 Gy applied to the involved parametria. The CHT group, 33 patients, were given the same treatment as the HDR group and received 5 or 6 weekly cycles of cisplatin, $40 \mathrm{mg}$ per $\mathrm{m} 2$.

Results. The five-year progression-free survival (PFS) was $60 \%$ for the HDR group and $45 \%$ for the LDR group, and the two-year PFS for the CHT group was $65 \%(p=0.02)$. The five-year Overall Survival (OS) was $65 \%$ for the HDR group and $49 \%$ for the LDR group. The two-year OS was $86 \%$ for the CHT group $(p=0.02)$. Rectum toxicity grade II was $7 \%$ for the LDR group, $4 \%$ for the HDR group and $7 \%$ for the $\mathrm{CHT}$ group that had one case of rectum toxicity grade IV.

ConcLusion. Patients that received HDR had better OS and PFS. The Chemotherapy-HDR association showed no benefit when compared to HDR only. Toxicity rates showed no difference between the three groups.
\end{abstract}

KEY WORDS: Uterine cervical neoplasms. Radiotherapy.Brachytherapy.Cisplatin.

\section{INTRODUCTION}

Carcinoma of the uterine cervix affects mainly women of low socioeconomic status and $80 \%$ of the cases occur in developing countries. Screening and vaccination are the best way to combat cervical cancer and the disease is prevented through tracking programs. However, incidence of advanced-stage tumors still remains very high in Brazil. Stage IIIB cervical cancer accounts for about $25 \%$ of cases diagnosed in our institution. In 2008, an estimated 21,560 of new cases of cervical cancer were diagnosed in Brazil'. Lack of cervical cancer awareness among the population, late stage at diagnosis and lack of specialized treatment centers interfere with the probability of curing the disease.

According to the International Federation of Gynecology and Obstetrics (FIGO), at stage IIIB the carcinoma has extended to the pelvic wall, hydronephrosis or a nonfunctioning kidney are found ${ }^{2}$. Brachytherapy plays an important role in managing patients with advanced-stage tumors, improving the four-year survival rate to $46 \%$ for stage IIIB disease, compared to only $19 \%$ for tumors treated with external beam radiation alone ${ }^{3}$. This form of therapy allows high doses of radiation to be beamed directly at the tumor, while neighboring tissues receive lower radiation doses. Teletherapy using high-energy photon beams, in the past was only associated with low-dose-rate brachytherapy (LDR). Now it is also performed with high-dose-rate brachytherapy (HDR) and more recently, combined with chemotherapy $y^{4,5,6,7}$.

Cervical cancer treatment for advanced-stage disease has undergone some changes in our institution since 1985. Accompanying changes in literature, we have made adjustments for the reality of our country. Until 1996, LDR was the brachytherapy used. With the introduction of high-dose-rate brachytherapy, in May 1996, treatment became an outpatient procedure available to many more patients ${ }^{8}$. Subsequently, our institution began to use chemotherapy plus concomitant radiotherapy to treat cervical cancer in 2003, supported by better results obtained from studies published in 1999 showing the benefits of combined therapy9,10,11.

This study aims to compare survival and toxicity rates of LDR, HDR and HDR plus chemotherapy for stage IIIB cervix cancer. An important feature of this study is the reported toxicity of the HDR and cisplatin association.

\footnotetext{
1. Médicos Especialistas da Universidade Estadual de Campinas, Campinas, SP

2. PhD - Chefe seção de radioterapia da Universidade Estadual de Campinas, Campinas, SP

3. PhD - Médico do departamento de Tocoginecologia da Universidade Estadual de Campinas, Campinas, SP
} 


\section{Methods}

This is an historical comparison between treatment regimens.

Between 1985 and 2005, two hundred and thirty (230) patients suffering from FIGO stage IIIB squamous cell (epidermoid) carcinoma of the uterine cervix were treated in our institution, with three different techniques ${ }^{1}$. All were included in this report, none had involvement of the lower third of the vagina, and their treatment results were retrospectively evaluated. All patients received 4 -field pelvic teletherapy, at doses ranging between 40 and $50.4 \mathrm{~Gy}$, with a different complementation in each group.

The LDR group, with 42 patients, mean age 54.3 years, treated between 1986 and 1996, received one or two insertions of LDR, with Cesium-137, reaching a total dose of 80 to 100Gy at point $A$ and were followed for 5 years.

The HDR group, 155 patients, mean age 56.5 years, treated between 1996 and 2003 with HDR in 4 weekly 7-Gy fractions to point $A$, using the ICRU 38 criteria for evaluation of the organs at risk. They had dose complementation ranging from 9 Gy to 14.4 Gy applied to the involved parametria, and were also followed for 5 years.

The CHT group, 33 patients, mean age 54.8 years, treated between 2003 and 2005 with the same treatment given to the HDR group, received 5 or 6 weekly cycles of $40 \mathrm{mg}$ of cisplatin per square meter of body surface area. These patients had a mean 2 year follow-up.

This study was reviewed and approved by the Research Ethics Committee of the institution.

\section{Follow-up and statistical analysis}

After treatment, patients were reassessed every four months during the first two years, every six months until the fifth year, and annually thereafter, on the basis of clinical examination, cervical cytology, imaging and laboratory tests. They were followed-up for five years, and loss to follow-up was 6\% (14 patients). Treatment toxicity was graded according to criteria of the Radiation Therapy Oncology Group RTOG) ${ }^{12}$. Overall survival (OS) was measured from onset of therapy to the date of death or most recent follow-up, progression free survival (PFS) was the period from time of biopsy to date of first documented evidence of disease-progression.

The Kaplan-Meier method was used to generate survival curves for comparison of treatment results. A log-rank test was used to analyze results. Patients without recurrent disease were excluded at their last follow-up visit or death. For all statistical tests, $\mathrm{P}<0.05$ was considered significant. All statistical analyses were performed using SPSS software (version 11.01. for Windows). Leadtoolsq 1991-2000 LEAD Technologies Inc.

\section{RESULTS}

Progression free survival (PFS) was higher for groups that underwent HDR. The five-year PFS was $60 \%(95 \% \mathrm{Cl}, 51.2-$ $68 \%)$ for the HDR group and $62 \%(95 \% \mathrm{Cl}, 36.7-79.5 \%)$ in two- year for the CHT group, compared to a five-year PFS of $45 \%(95 \% \mathrm{Cl}, 28.9-59.4 \%)$ in the LDR group receiving lowdose-rate-brachytherapy ( $p=0.02)$. There was no difference between the HDR and CHT groups (Figure 1 ). The same pattern was observed for overall survival (OS). The five-year OS was
$65 \%$ (95\% Cl, 52.2-73\%) for the HDR group and the two-year OS was $86 \%(95 \% \mathrm{Cl}, 71.5-95.5 \%)$ for the CHT group, when compared to $49 \%(95 \% \mathrm{Cl}, 32.3-63.2 \%)$ for the LDR group ( $p$ $=0.02$ ). No difference was observed in survival rates between HDR and CHT groups in the period studied (Figure 2).

Rectum toxicity grade II occurred in 3 patients $(7 \%)$ in the LDR group, 6 patients (4\%) in the HDR group and 3 patients (7\%) in the CHT group. In the study only one case of grade IV rectal toxicity was described in the $\mathrm{CHT}$ group.

\section{Discussion}

The current study used a time-series design to evaluate therapeutic response. Women receiving HDR showed improved rates of local control and overall survival, when compared to those receiving LDR. In our institution, patients treated with LDR had been treated many years before, possibly explaining the difference between HDR and LDR treatment. In the past, there was a longer delay in cancer diagnosis than nowadays and tumor volume was probably greater. Using an outpatient procedure such as HDR decreased treatment time and improved

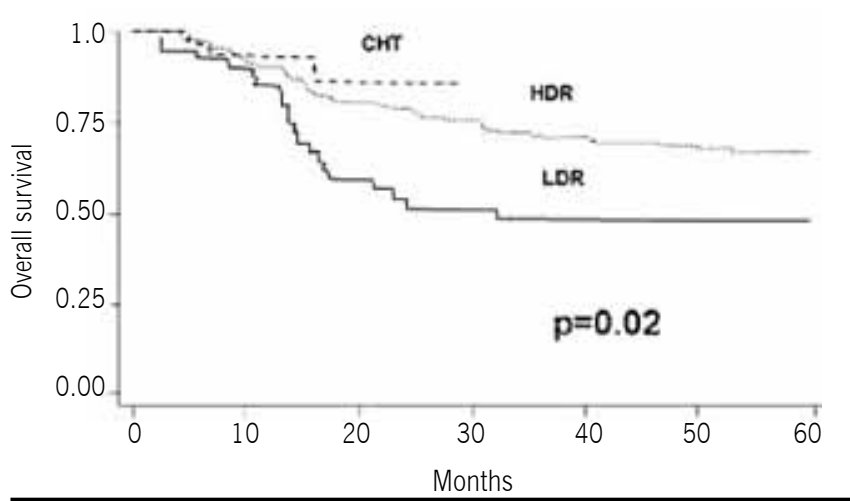

Overall survival, by treatment group, calculated by Kaplan-Meier method. HDR = high dose rate brachytherapy; LDR = low dose rate brachytherapy; $\mathrm{CHT}=$ chemotherapy + HDR.

therapeutic response.

Cervical carcinoma has been treated with HDR in our institution since 1996. HDR proved to be as clinically effective as LDR in the management of cervical cancer. In rates of survival, relapse and complications, no statistically significant differences have been found between both treatment methods $2,3,4,14,15,16,17$.

According to Arai et al., the five-year overall survival rate for women with epidermoid carcinoma of the uterine cervix treated with HDR was $88.1 \%$ for stage IB, $76.9 \%$ for stage II , $67 \%$ for stage IIB, $52.2 \%$ for stage IIIB, $24.1 \%$ for stage IVA and $13.3 \%$ for stage IVB of the disease ${ }^{1}$.Ferrigno found poorer results for stage III disease treated with HDR, regarding overall and progression free survival. According to the authors, the reason for these results may be the low doses used in HDR ${ }^{18}$.

Grades III and IV complication rates for all three treatment groups were equivalent to those found in literature.

In a study by Peiteret et al., acute major complications, 
requiring hospitalization were observed in $5.5 \%$ of women receiving HDR for cervical cancer. The 30-day mortality rate was $1.6 \%$. Some identified risk factors, including advanced patient age and a low Karnofsky performance status, increased the chance of acute events occurring due to treatment ${ }^{15}$. Another study described late complications requiring treatment in about $11 \%$ of women undergoing HDRB. The most commonly affected site, was the rectum followed by the urinary bladder ${ }^{3}$.

Patients who suffered from stage IIIB squamous cell carcinoma of the uterine cervix who were treated with HDRB had a better disease-free survival rate than those treated with the previously employed LDR therapy. While the HDR and CHT groups showed better results than the LDR group, all response rates are consistent with the literature. Since the LDR group had been treated many years before, we believe that these patients may have received a late diagnosis with worse clinical support, and thus worse results. Combined modality therapy (chemotherapy and radiation therapy) was performed in a small group of patients with only a short follow-up. Until now, the rates of overall survival and progression free survival have not shown any significant improvement in these patients.

Attempts to combine radiation therapy with chemotherapy originated many years ago ${ }^{19}$. Several papers have demonstrated that neoadjuvant chemotherapy was of no benefit for patients ${ }^{20,21}$.

In 1999, the North American National Cancer Institute called attention to publications of phase III studies, showing that patients treated with radiotherapy plus concomitant platinumbased chemotherapy obtained greater benefits ${ }^{22}$. While these studies described differences regarding stage of disease, dose of radiation, use of HDR or LDR, all benefited from the combined treatment. Other studies have questioned this association, demonstrating that combined treatment failed to provide any benefits for patients with advanced-stage tumors. However, patients with early-stage cancer have benefited from concomitant treatment after surgery, ${ }^{23,24}$ although more recent trials did not confirm these data 25 .

In this study, patients that received HDR had better OS and PFS. The chemotherapy-HD association showed no benefit when compared to HDR only, and toxicity rates showed no difference between the three groups. Randomized controlled trials are necessary to confirm these data ${ }^{26}$, but the association of chemotherapy and HDR seems to be an acceptable treatment in these cases $^{27}$.

\section{Conflict of interest: none}

\section{Resumo}

\section{BRAQUITERAPIA PARA CARCINOMA EPIDERMÓIDE DO COLO DO ÚTERO ESTÁDIO IIIB: SOBREVIDA E TOXICIDADE}

OBJetivo. Comparar três diferentes tratamentos para câncer de colo do útero, estádio IIIB: braquiterapia de baixa taxa de dose (LDR), alta taxa de dose (HDR) e associação entre HDR e quimioterapia, quanto à sobrevida e toxicidade.

MéTodos. Entre 1985 e 2005, 230 pacientes com carcinoma epidermoide de colo do útero estádio IIIB receberam teleterapia pélvica em quatro campos, doses entre 40 e 50.4 Gy, e três complementações diferentes. Grupo LDR, com 42 pacientes, recebeu uma ou duas inserções de $L D R$, com Césio-137, na dose total de 80 a 100Gy no ponto A. Grupo HDR, 155 pacientes, com HDR em quatro frações semanais de 7 Gy, e 9 Gy a 14.4 Gy nos paramétrios acometidos. Grupo CHT, 33 pacientes, tratadas da mesma forma que o grupo HDR, mais cinco ou seis ciclos semanais de cisplatina, $40 \mathrm{mg}$ por $\mathrm{m} 2$.

RESUltados. A sobrevida livre de progressão em cinco anos (PFS) foi 60\% no grupo HDR e 45\% no grupo LDR, e a PFS em dois anos para o grupo CHT foi $65 \%(p=0.02)$. A sobrevida global em cinco anos (OS) foi $65 \%$ para o grupo HDR e $49 \%$ para o grupo LDR. A OS em dois anos foi $86 \%$ para o grupo CHT ( $p=0.02)$. Toxicidade retal grau I/ foi $7 \%$ no grupo $L D R$, $4 \%$ no grupo HDR e $7 \%$ no grupo CHT, que teve um caso de toxicidade retal grau IV.

Conclusão. Pacientes que receberam HDR tiveram melhores índices de sobrevida. A associação quimioterapia-HDR não mostrou benefício quando comparada com apenas HDR. Os indices de toxicidade não foram diferentes. [Rev Assoc Med Bras 2010; 56(1): 37-40]

Unitermos: Neoplasias do colo do útero. Radioterapia. Braquiterapia. Quimioterapia.

\section{REFERENCES}

1. Brasil. Ministério da Saúde. Secretaria de Atenção à Saúde. Instituto Nacional de Câncer. Coordenação de Prevenção e Vigilância. Estimativa 2008: Incidência de câncer no Brasil. Rio de Janeiro; 2007.

2. Lanciano RM, Martz K, Coia LR, Hanks GE. Tumor and treatment factors improving outcome in stage III-B cervix cancer. Int J Radiat Oncol Biol Phys. $1991 ; 20: 95-100$

3. Shigematsu Y, Nishiyama K, Masaki N, Inoue T, Miyata Y, Ikeda H, et al. Treatment of carcinoma of the uterine cervix by remotely controlled afterloading intracavitary radiotherapy with high-dose rate: a comparative study with a low-dose rate system. Int J Radiat Oncol Biol Phys. 1983;9:351-6.

4. Teshima T, Chatani M, Hata K, Inoue T. High-dose rate intracavitary therapy for carcinoma of the uterine cervix: I. General figures of survival and complication. Int J Radiat Oncol Biol Phys. 1987;13:1035-41.

5. Orton CG. High and low dose-rate brachytherapy for cervical carcinoma. Acta Oncol. 1998; 37:117-25.

6. Eifel PJ, Winter K, Morris M, Levenback C, Grigsby PW, Cooper J, et al. Pelvic irradiation with concurrent chemotherapy versus pelvic and para-aortic irradiation for high-risk cervical cancer: an update of radiation therapy oncology group trial (RTOG) 90-01. J Clin Oncol. 2004;22:872-80.

7. Esteves SB, Oliveira AZ, Feijó LA. Braquiterapia de alta taxa de dose no Brasil. Radiol Brás. 2004;37:337-41.

8. Whitney CW, Sause W, Bundy BN, Malfetano JH, Hannigan EV, Fowler WC Jr, et al. Randomized comparison of fluorouracil plus cisplatin versus hydroxyurea as an adjunct to radiation therapy in stage IIB-IVA carcinoma of the cervix with negative para-aortic lymph nodes: a Gynecologic Oncology Group and Southwest Oncology Group study. J Clin Oncol. 1999;17:1339- 48.

9. Morris M, Eifel PJ, Lu J, Grigsby PW, Levenback C, Stevens RE, et al. Pelvic radiation with concurrent chemotherapy compared with pelvic and para-aortic radiation for high-risk cervical cancer. N Engl J Med. 1999;340:1137-43.

10. Rose PG, Bundy BN, Watkins EB, Thigpen JT, Deppe G, Maiman MA, et al. Concurrent cisplatin-based radiotherapy and chemotherapy for locally advanced cervical cancer. N Engl J Méd. 1999;340:1144-53.

11. Benedet JL, Bender H, Jones H $3^{\text {rd }}$, Ngan HY, Pecorelli S. FIGO staging classifications and clinical practice guidelines in the management of gynecologic cancers. FIGO Committee on Gynecologic Oncology. Int J Gynaecol Obstet. 2000;70:209-62.

12. Cox JD, Stetz J, Pajak TF. Toxicity criteria of the Radiation Therapy Oncology Group (RTOG) and the European Organization for Research and Treatment of Cancer (EORTC). Int J Radiat Oncol Biol Phys. 1995;31:1341-6.

13. Aisen S, Carvalho HA, Chavantes MC, Esteves SC, Haddad CM, Permonian $A C$, et al. High dose rate brachytherapy. Rev Hosp Clin Fac Med São Paulo. 1992;47:121-4.

14. Arai T, Nakano T, Morita S, Sakashita K, Nakamura YK, Fukuhisa K. Highdose-rate remote afterloading intracavitary radiation therapy for cancer of the uterine cervix. A 20-year experience. Cancer. 1992; 69:175-80.

15. Petereit DG, Sarkaria JN, Chappell RJ. Perioperative morbidity and mortality of high-dose-rate gynecologic brachytherapy. Int J Radiat Oncol Biol Phys. 1998;42:1025-31. 
16. Lertsanguansinchai P, Lertbutsayanukul C, Shotelersuk K, Khorprasert C,Rojpornpradit P, Chottetanaprasith $\mathrm{T}$, et al. Phase III randomized trial comparing LDR and HDR brachytherapy in treatment of cervical carcinoma. Int J Radiat Oncol Biol Phys. 2004;59:1424-31.

17. Nakano T, Kato S, Cao J, Zhou J, Susworo R, Supriana N, et al. A regional cooperative clinical study of radiotherapy for cervical cancer in east and southeast Asian countries. Radiother Oncol. 2007;84:314-19.

18. Ferrigno R, Nishimoto IN, Novaes PE, Pellizzon AC, Maia MA, Fogarolli RC, et al. Comparison of low and high dose rate brachytherapy in the treatment of uterine cervix cancer. Retrospective analysis of two sequential series. Int J Radiat Oncol Biol Phys. 2005;62:1108-16.

19. Thomas G, Dembo A, Beale F, Bean H, Bush R, Herman J, et al. Concurren radiation, mitomycin $\mathrm{C}$ and 5 -fluorouracil in poor prognosis carcinoma of cervix: preliminary results of a phase I-II study. Int J Radiat Oncol Biol Phys. 1984;10:1785-90.

20. Souhami L, Gil RA, Allan SE, Canary PC, Araújo CM, Pinto LH, et al. A randomized trial of chemotherapy followed by pelvic radiation therapy in stage IIIB carcinoma of the cervix. J Clin Oncol. 1991;9:970-7.

21. Tattersall MH, Lorvidhaya V, Vootiprux V, Cheirsilpa A, Wong F, Azhar T, et al. Randomized trial of epirubicin and cisplatin chemotherapy followed by pelvic radiation in locally advanced cervical cancer. Cervical Cancer Study Group of the Asian Oceanian Clinical Oncology Association. J Clin Oncol. 1995; 13:444-51

22. National Cancer Institute: NCl Clinical Announcement. Bethesda, MD, United States Department of Health and Human Services, Public Health Service, National Institutes of Health; 1999.
23. Pearcey R, Brundage M, Drouin P, Jeffrey J, Johnston D, Lukka H, et al. Phase III trial comparing radical radiotherapy with and without cisplatin chemotherapy in patients with advanced squamous cell cancer of the cervix. J Clin Oncol. 2002; 20:966-72

24. Peters WA 3rd, Liu PY, Barrett RJ 2nd, Stock RJ, Monk BJ, Berek JS, et al. Concurrent chemotherapy and pelvic radiation therapy compared with pelvic radiation therapy alone as adjuvant therapy after radical surgery in high-risk early-stage cancer of the cervix. J Clin Oncol. 2000;18:1606-13.

25. Nagy V, Coza O, Ordeanu C, Trãilã A, Rancea A, Todor N, et al. Radiotherapy versus concurrent 5 -day cisplatin and radiotherapy in locally advanced cervical carcinoma. Long-term results of a phase III randomized trial. Strahlenther Onkol. 2009;185:177-83.

26. Tewari KS, Monk BJ. Recent achievements and future developments in advanced and recurrent cervical cancer: trials of the Gynecologic Oncology Group. Semin Oncol. 2009;36:170-80.

27. Narayan K, van Dyk S, Bernshaw D, Rajasooriyar C, Kondalsamy-Chennakesavan S. Comparative study of LDR (Manchester system) and HDR
Artigo recebido: 03/02/09 Aceito para publicação: 01/09/09 